\title{
YY1 wt Allele
}

National Cancer Institute

\section{Source}

National Cancer Institute. YY1 wt Allele. NCI Thesaurus. Code C102472.

Human YY1 wild-type allele is located within $14 \mathrm{q}$ and is approximately $44 \mathrm{~kb}$ in leng th. This allele, which encodes transcriptional repressor protein $\mathrm{YY} 1$, plays a role in both transcriptional repression and DNA repair. 